\title{
The Refugee Crisis and the Return of the East-West Divide in Europe
}

\author{
Ivan Krastev
}

In his novel Death with Interruptions (2005), José Saramago imagines a society where people will live so long that death will lose its central role in human life. ${ }^{1}$ At first, people are gripped by euphoria but soon "awkwardness" of various kinds-metaphysical, political, and practical-starts to reenter their world. The Catholic Church realizes that "without death there is no resurrection, and without resurrection there is no church." For insurance companies, life without death also means oblivion. The state faces the impossible task of paying pensions forever. Families with elderly and infirm relatives understand that only death saves them from an eternity of nursing care. A mafia-style cabal emerges to smuggle old and sick people to neighboring countries to die (since death is still an option there). The prime minister warns the monarch: "If we don't start dying again, we have no future."

Europe's experience with globalization, meant to be a world without borders, resembles Saramago's imagined flirt with immortality. The initial euphoria born out of the fall of walls has been replaced by anxiety and demand for building new fences. What was a dream became a nightmare. Interdependence, heralded as the source of security, turned out to be the major source of insecurity.

A decade ago, the Hungarian philosopher and former dissident Gáspár Miklós Tamás observed that the Enlightenment, in which the idea of the European Union is intellectually rooted, demands universal citizenship. But universal citizenship requires one of two things to happen: either poor and dysfunctional countries have to become places in which it is worthwhile to be a citizen, or Europe has to open its borders to everybody. Neither is going to happen anytime soon, if ever. In a world of vast inequalities and open borders, however, migration comes as the new form of revolution.

People no longer dream of the future but of other places. In this connected world, migration-unlike the utopias sold by the last century's demagoguesinstantly offers radical change. It requires no ideology, political movement, or political leader. You change not the government but the geography. The absence of collective dreams makes migration the natural choice of the new radical who cherishes his legs more than his vote. To change your life you need a boat, not a political party. With social inequality rising and social mobility stagnating in many countries in the world, it is easier to cross national borders than class barriers.

Of the many crises that Europe faces today it is the migration crisis that defines the changing nature of European politics. Large segments of European publics associate migration with the rising risk of terrorist attacks, with Islamization of European societies, and the dismantling of the welfare state. It is the problem of migration that is the defining issue for the popularity

1. José Saramago, Death with Interruptions, trans. Margaret Jull Costa (Boston, 2005). 
of right-wing populism in Europe. It is demand for control of immigration that decided Britain's referendum on Europe, and it is the refugee crisis that brought back the east-west divide in the EU, thus defeating the assumption that the convergence fueled by integration is irreversible.

Migration is not simply the influx of people (refugees or labor migrants), it is among many other things an influx of images and emotions and arguments. It has signaled that threatened majorities have emerged as a major force in European politics. These threatened majorities fear that foreigners are taking over their countries and threatening their way of life, and they are convinced that the current crisis is brought on by a conspiracy between cosmopolitanminded elites and tribal-minded immigrants. They do not represent the aspirations of the repressed but rather the frustration of the empowered. It is not a populism of "the people" held in thrall by the romantic imagination of nationalists, as was the case a century and more ago, but a populism fueled by the demographic projections about the shrinking role of Europe in the world to come and the expected mass movements of people to Europe. It is a kind of populism for which history and precedent have poorly prepared us.

What we witness today in Europe is not what Brussels describes as a lack of solidarity, but a clash of solidarities: national, ethnic and religious solidarity chafing against our moral and legal obligations with respect to the refugees. In the 1920s, the number of refugees who came to Bulgaria amounted to a quarter of its population. Bulgaria then looked like Jordan and Lebanon today, and Bulgarians are rightly proud that in a very short time they succeeded in integrating these people. They did it because the refugees were their own, ethnic Bulgarians, coming from Bulgarian lands that remained part of the Ottoman Empire after the resurrection of independent Bulgaria in 1878. But Bulgarians do not agree that the solidarity that they owe to their own people should also be extended to others running from war and persecution. Presently, more Bulgarians volunteer to carry out "civic arrests" of refugees illegally crossing the borders than volunteer to help them. The refugee crisis has made it clear that the European east views the very cosmopolitan values on which the European Union is based as a threat, while for many in the west it is precisely those cosmopolitan values that are the core of the new European identity. The migration crisis is destroying the illusion that the convergence between European west and European east, which started after the end of the Cold War, is irreversible. In addition, it is the return of the east-west divide, more than any other political development, that fuels fears of full or partial disintegration of the EU.

"I can comprehend only with difficulty," German president Joachim Gauck confessed, "when precisely those nations whose citizens, once themselves politically oppressed and who experienced solidarity, in turn withdraw their solidarity for the oppressed." 2

So why is it that central Europeans have today become so estranged from the fundamental values that underpin the European Union that they are

2. Joachim Gauck, quoted in Andrew Rettman, "Austria imposes asylum cap to 'shake up’ Europe,” Euobserver, January 20, 2016, at www.euobserver.com/justice/131928 (last accessed February 9, 2017). 
unwilling to show solidarity with the sufferings of others? Why did they risk opposing Brussels and Berlin at the moment when European unity is being defined as the major pre-condition for getting out of the current combination of crises?

The scandal of east Europeans' behavior as viewed from the west is not their readiness to build fences to keep out refugees at the very places where walls were destroyed only 25 years ago, but their claim that "we do not owe anything to these people." Migration is a dividing issue in the west, too, and the last wave of terrorist attacks increased the number of critics of German Chancellor Angela Merkel's welcome policy. But while in Germany almost 10 percent of the population took part in various volunteer initiatives aimed at helping the asylum seekers, the public in eastern Europe remains unmoved by the tragedy of the refugees, and leaders there have lambasted Brussels's decision to redistribute refugees among European Union member states. Prime Minister Robert Fico of Slovakia has asserted that his country would be prepared to accept only Christians; there are no mosques in Slovakia, he argued, so Muslims would have nothing to do in his country. The leader of the governing Law and Justice Party in Poland, Jarosław Kaczyński, warned that accepting refugees is a health risk because they would bring unknown and dangerous diseases with them. Hungary's PM Viktor Orbán argues that the European Union's moral duty is not to help the refugees, but to guarantee the security of its own citizens.

The central European resentment of refugees looks odd if we take into account two things: first, that for most of the twentieth century people in central and eastern Europe were preoccupied either with emigrating or with taking care of immigrants. Second, that at present there are simply no Syrian refugees in most central and east European countries.

While east Europeans' hostility towards refugees could be shocking to many, it should not be surprising. It has its roots in history, demography, and the twists of post-communist transition, while at the same time representing a central European version of popular revolt against globalization.

History matters in central and eastern Europe, and very often the region's historical experience contradicts some of the promises of globalization. More so than any other place in Europe, central Europe is aware of the advantages, but also of the dark sides of multiculturalism. East European states and nations emerged late in the nineteenth century, and they did so almost simultaneously. While in the western half of Europe it was the legacy of the colonial empires that shaped encounters with the non-European world, central European states were born of the disintegration of empires and the processes of ethnic cleansing that followed. The nineteenth-century ethnic landscape of western Europe was harmonious, like a Caspar David Friedrich landscape, whereas that of central Europe was more like a Kokoschka. While in the prewar period Poland was a multicultural society where more than a third of the population was German, Ukrainian, or Jewish, today Poland is one of the most ethnically homogeneous societies in the world, with 98 percent of the population being ethnic Poles. For many of them the return to ethnic diversity is a return to the troubled times of the interwar period. It was the destruction and expulsion of the Jews and Germans that led to the establishment of national 
middle classes in central Europe. While the European Union is founded on the French notion of the nation (where belonging is defined as loyalty to the institutions of the Republic) and the German notion of the state (powerful Länder and a relatively weak federal center), central European states were built on the reverse: they combine a French admiration for the centralized and all-powerful state with the idea that citizenship means common descent and shared culture, as held by the Germans.

In the view of the French political scientist Jacques Rupnik, central Europeans have been particularly outraged by Germany's criticism directed against them during the refugee crisis, because it was precisely from nineteenth-century Germans that central Europeans borrowed the idea of the nation as cultural unity.

Central Europe's resentment of the refugees is rooted not only in its long history, however, but also in the experiences of post-communist transition. What came after communism and liberal reforms was pervasive cynicism. Central Europe is a world champion in the mistrust of institutions. Brecht is no longer part of the school curriculum, but many east Europeans will be ready to subscribe to the notion that "for this world we live in, none of us is bad enough." Faced with an influx of migrants and haunted by economic insecurity, many east Europeans feel betrayed in their hope that joining the European Union would mean the beginning of prosperity and life without crises. Being poorer than western Europeans, they point out, how can anyone expect solidarity from us?

Curiously, demographic panic is one of the least discussed factors shaping east Europeans' behavior towards refugees. Nevertheless, it is a critical one. Nations and states have the habit of disappearing in the recent history of eastern and central Europe. In the last 25 years, around 10 percent of Bulgarians have left the country in order to live and work abroad. According to United Nations projections, Bulgaria's population is expected to shrink by 27 percent by 2050. Alarm over "ethnic disappearance" can be felt in many of the small nations of eastern Europe. For them, the arrival of migrants signals their exit from history, and the mostly western economic argument that an aging Europe needs migrants only strengthens the growing sense of existential melancholy. When you watch on television scenes of elderly locals protesting the settlement of refugees in their depopulated villages, where not a single child has been born for decades, your heart breaks for both sides-the refugees, but also the old, lonely people who have seen their worlds melt away. You can hear retired literature teachers asking, is there going to be anyone left to read Bulgarian poetry in 100 years? Moreover, communist-imposed secularism made central and east Europeans very sensitive to the risk of the destruction of their Christian identity. One does not need to be a believer today to be worried about the future of Christianity and its culture in central and eastern Europe. It is also worth remembering that central and eastern Europe is the part of Europe that has probably the most complex relationship with Islam. In that region, two types of countries exist: countries like Bulgaria, which has the biggest Muslim minority in the European Union and is on the border with the Muslim world, and countries like Slovakia, a country without a single 
mosque. For opposite reasons, both Bulgaria and Slovakia feel very nervous about most of the refugees being Muslims.

The failed integration of the Roma also contributes to eastern Europe's compassion deficit. East Europeans fear foreigners because they mistrust the capacity of their society and state to integrate the "others" already in their midst. In many east European countries, the Roma are not simply unemployed but unemployable, because they drop out of school very early and fail to acquire the skills needed for the twenty-first-century job market. The failure of Roma integration makes east Europeans believe that their countries "cannot do it." In addition, the fact that east Europeans and refugees coming from Asia or the Middle East quite often end up as competitors on the western job market does not make east Europeans more open to the politics of integrating those refugees. Citizens of western Balkan countries are probably the most powerful example of the collateral damage of the current crisis-according to the plan to deal with the growing influx of refugees entering Germany, Kosovars and Bosnians are to be sent back home without the hope that they can one day return to the EU.

At the end of the day, however, it is central Europe's deeply-rooted mistrust towards a cosmopolitan mindset that divides east and west. The current resentment of cosmopolitanism, which in many aspects reminds us of the successes of the anti-cosmopolitan campaigns in Stalin-dominated Europe, is aptly symbolized by the growing eagerness of voters to support nativist political leaders whose major advantage is that they are not interested in the world, do not speak foreign languages, have no interest in foreign cultures, and avoid visiting Brussels.

The attitude divide between Europe's west and east on the issues of diversity and migration strongly resembles the divide between the big cosmopolitan capital cities and the countryside within western societies themselves, two worlds deeply mistrustful of each other. It is interesting to note that while the generational differences are very sharp when it comes to tolerance of sexual minorities and while young east Europeans are much more liberal than their parents, when it comes to migration the generation gap does not exist: the young are as hostile as the old.

Writer Joseph Roth spent most of the interwar years wandering around Europe and taking refuge in the lobbies of grand hotels, because for him hotels were the last remnants of the old Habsburg Empire, a postcard from a lost world, a place where he felt at home. Some central European intellectuals do share Roth's nostalgia for the cosmopolitan spirit of the empire, but ordinary citizens of central Europe do not. They feel comfortable in their ethnic states and deeply mistrust those whose hearts are in Paris or London, whose money is in New York or Cyprus and whose loyalty is to Brussels. In Tony Judt's words, “from the outset eastern and 'central' Europeans, whose identity consisted largely in a series of negatives-not Russian, not Orthodox, not Turkish, not German, not Hungarian and so forth-had provinciality forced upon them as an act of state-making. Their elites were obliged to choose between cosmopolitan allegiance to an extraterritorial unit or idea-the Church, an empire, Communism, or, most recently 'Europe'-or else the constricting horizon of 
nationalism and local interest." ${ }^{3}$ Being cosmopolitan and at the same time a "good Pole," "good Czech," or "good Bulgarian" is not in the cards. This historically-rooted suspicion of anything cosmopolitan, and the direct connection between communism and internationalism, partially explain central Europe's sensitivities when it comes to the refugee crisis. Eastern Europe's run away from internationalism is not much different than what happens to the working class in western societies. In Austria, almost 80 percent of the blue-collar workers voted for the far-right candidate in the last presidential elections. In the German regional elections, more than 30 percent of the same group supported Alternative for Germany. In the French regional elections in December 2015, the National Front scored 50 percent among working-class voters. The results of the British referendum are striking: Brexit polled strongest in the traditional "safe" Labour seats in the north of England. In many ways, east Europeans, who are the poorest members of the EU, share the fears of the blue-collar workers in the west. They dream for the European Union to be able and willing to defend them from the economic and cultural changes brought by globalization.

In making sense of the east-west divide when it comes to the endorsement of cosmopolitan values, we should also keep in mind that in this respect the legacies of Nazism and Communism significantly differ. The Germans' drive for cosmopolitanism was also a way for them to flee the xenophobic legacy of Nazism, while it could be argued that central Europe's anti-cosmopolitanism is partially rooted in an aversion to communist-imposed internationalism.

So, how important will the east-west divide in Europe, caused by responses to the refugee crisis, be for the future of the European Union? Is it going to fade away or will it lead to the emergence of a two-tier European Union?

What I want to argue is that the refugee crisis is a turning point in central and east European societies' attitudes toward the European Union, because if previously central Europeans' mistrust towards their own corrupt elites and governments was a source of trust in the EU, after the refugee crisis publics in the region are more likely to trust their own governments, regardless of how corrupt or incompetent they are, rather than Brussels. The re-nationalization of sentiment is the new reality in Europe. In many respects the attitudes of the populist governments in central and eastern Europe resemble the behavior and attitudes held by the second generation of migrants in Europe towards their host country. If the first generation of central European leaders, politicians like Vaclav Havel, made integration into the EU their life's cause and tried to prove that central Europeans could be more European than the westerners, the new generation of leaders experience the process of the constant adoption of European norms and institutions as humiliation, and build their legitimacy around the idea of a national identity in opposition to Brussels.

3. Tony Judt, A Grand Illusion?: An essay on Europe (New York, 2011), 57. 